\title{
Multiple metal tolerance of Paenibacillus dentritiformis isolated from metal contaminated soils west Godavari district (Andhra Pradesh)
}

\section{Sridevi}

Department of Botany and Microbiology, Acharya Nagarjuna University, Nagarjuna Nagar, Guntur Dist. (A.P.), India

\section{Raghuram*}

Department of Botany and Microbiology, Acharya Nagarjuna University, Nagarjuna Nagar, Guntur Dist. (A.P.), India

${ }^{*}$ Corresponding author. E-mail: mraghuram2002@gmail.com

\begin{abstract}
Sugar industrial effluents possess high amounts of toxic pollutants and contaminate the receiving sites. Treatment of contaminated sites by using microorganisms provides an alternate to conventional methods hence demands in the identification of metal tolerant microorganisms has been increasing day by day. Therefore in this study soil samples collected from Tanuku sugar factory residual effluent point (bank of Gosthani river), west Godavari district A.P were analyzed for the bacterial tolerance to Copper $(\mathrm{Cu})$, Zinc $(\mathrm{Zn})$ and Lead $(\mathrm{Pb})$ in their chloride forms. Additionally, the study was carried out to identify the metal tolerant bacteria by morphological, biochemical and 16S rRNA gene sequencing studies. Four potential bacterial isolates were selected to analyze metal tolerance against $\mathrm{CuCl}_{2}, \mathrm{ZnCl}_{2}$, and $\mathrm{PbCl}_{2}$. The sequences were compared with those in $\mathrm{NCBI}$ and submitted in gene bank with accession numbers MK100333 (Paenibacillus cookie), MK100334 (Bacillus cereus), MK100335 (Aneurini bacillus $s p$ ) and MK100387 (Paenibacillus $s p$.). A Phylogenetic tree was constructed to Paenibacillus $s p$. the highly efficient bacterial strain among the four isolates using MEGA 7 soft ware. The results of this study showed that $P$. dentritiformis had multiple metal tolerances $(\mathrm{Cu}, \mathrm{Zn}$ and $\mathrm{Pb})$ up to $500 \mathrm{mg} / \mathrm{L}$ after $72 \mathrm{hrs}$. The identified bacterial strain proved to be the strong heavy metal tolerant bacterial strain. Hence, its usage will be helpful in the treatment of heavy metals specifically $\mathrm{Cu}, \mathrm{Zn}$ and $\mathrm{Pb}$ contaminated soils and further optimization of these cultures is required to improve its metal resistant capacity.
\end{abstract}

Keywords: Copper, Lead removal, Metal tolerance, Paenibacillus species, Zinc removal, 16s rRNA gene sequencing

\section{INTRODUCTION}

Heavy metals have relatively high atomic weight and density compared to water and occurring naturally in environment. Now a day's heavy metal contamination is an important environmental concern globally. These heavy metals can become mobile in soils depending on soil $\mathrm{pH}$ and can leach to nearby aquatic forms or to living organisms (Hookoom and Puchooa, 2013). The concentration of heavy metals is being increased due to rapid industrialization day by day. The industrial wastewater mainly contains the heavy metals like Cadmium, chromium, mercury, lead, nickel, cobalt, Zinc and copper (Smrithi and Usha, 2012). Removal of heavy metals by using microbes has attained a great attention from past few years. Many literatures have been reported so far on metal tolerant microbes and removal of heavy metals from aqueous solutions by using microor-

\section{Article Info}

DOI:10.31018/jans.v11i2.2094

Received: April 28, 2019

Revised: June 1, 2019

Accepted: June 7, 2019

\section{How to Cite}

Sridevi, V. and Raghuram, M. (2019). Multiple metal tolerance of Paenibacillus dentritiformis isolated from metal contaminated soils west Godavari district (Andhra Pradesh). Journal of Applied and Natural Science, 11(2): 486- 491 https://doi.org/10.31018/ jans.v11i2.2094 
In addition, the use of stream and river water that has contaminated with sugar factory effluent causes a serious health hazards in humans. Untreated effluent from sugar factory creates an unpleasant odor when released into the environment (Usha Damodhar and Vikram Reddy, 2012).

Therefore, it is need of the time to analyze these wastes for some indigenous strains of heavy metal tolerant bacteria and to explore their potential in bioremediation of common heavy metals founds in such effluents. Keeping in view the above, present study was conducted for the isolation, identification and molecular characterization of heavy metal tolerant bacteria against $\mathrm{Cu}, \mathrm{Zn}$ and $\mathrm{Pb}$ which are common in Tanuku sugar factory industrial effluents west Godavari district A.P

\section{MATERIALS AND METHODS}

Study area: Samples were collected from metal contaminated site i.e Gosthani River bank one of the residual effluent point near by Tanuku sugar factory, Tanuku, West Godavari district Andhra Pradesh.

Sample collection: Soil samples were collected from the bank of Gosthani River at a depth of $1 \mathrm{~cm}, 5 \mathrm{~cm}$ and $10 \mathrm{~cm}$ into sterile zip lock bags with a sterile spatula and transferred to the laboratory. Samples were stored at room temperature.

Metal analysis: Collected soil samples were analyzed for the presence of 9 heavy metals specifically $\mathrm{Ni}, \mathrm{Cd}, \mathrm{Hg}, \mathrm{Mn}, \mathrm{Mg}, \mathrm{Ar}, \mathrm{Pb}, \mathrm{Cu}$ and $\mathrm{Zn}$ by Atomic absorption spectrophotometer (Model number: OPTIMA 8000, Category ICP-OES) following the Elemental analysis technique method. Standard preparation: Mixed elemental standard was prepared using $100 \mathrm{ppm}$ is mentioned below. Transferred $0.25 \mathrm{ml}, 05 \mathrm{ml}$ and $0.75 \mathrm{ml}$ of $100 \mathrm{ppm}$ mixed standard in to three separate $50 \mathrm{ml}$ volumetric flasks and diluted up to mark with milli $Q$ water to obtained $0.5 \mathrm{ppm}, 1 \mathrm{ppm}$ and $1.5 \mathrm{wg} / \mathrm{L}$ respectively.

Sample preparation: Five $\mathrm{ml}$ of concentrated HNO3 and $20 \mathrm{ml}$ of water was added to five grams of soil sample in a beaker. The sample was digested at $80^{\circ} \mathrm{C}$ by using a hot plate for about 30 minutes; followed by cooling and diluted in $100 \mathrm{ml}$ flask with water (Filtered the solution and aspirated it).

Isolation of metal resistant bacteria: Soil samples were immediately processed after bringing to the laboratory by following 10 fold serial dilutions up to $10^{-7}$ in sterile test tubes. $0.1 \mathrm{ml}$ from $10^{-5}, 10^{-6}$ and $10^{-7}$ of each soil sample was spread uniformly on to a sterile nutrient agar plates individually with a bent glass rod. Plates were incubated at $37^{\circ} \mathrm{C}$ for 24 hours. Nearly 256 bacterial colonies were screened for metal tolerance out of which four bacterial strains were selected randomly with different morphological appearance from that culture plates (Table: 1). Purification is done by streaking repeatedly on sterile nutrient agar plates and until further analysis pure cultures are maintained on agar slants at refrigerator temperature (Ansari.,2016).

Determination of metal tolerance: The maximum metal tolerable efficiency of selected strains were performed (Seralathan et al., 2008; Shameer Syed and Paramageetham Chinthala, 2015; and Murthy et al., 2013) by inoculating bacterial strains into serial concentrations of $\mathrm{Cucl}_{2}, \mathrm{Zncl}_{2}$ and $\mathrm{Pbcl}_{2}$ (100mg/L, 200mg/L, 300mg/L, 400mg/L, 500mg/L and $600 \mathrm{mg} / \mathrm{L}$ ) in nutrient broth at their respective $\mathrm{pH}$ and maintained each tube at $37^{\circ} \mathrm{C}$ in triplicates and O.D values were taken at 72 hours.

Stock solution preparation: Stock solutions of the heavy metals were prepared by using copper chloride, Zinc chloride, and lead chloride. The stock solutions with $1000 \mathrm{ppm}$ concentration of respective metal were prepared in de-ionized water by dissolving $2.68 \mathrm{gm}, 2.08 \mathrm{gm}$ and $1.3 \mathrm{gm}$ of $\mathrm{Cucl}_{2}, \mathrm{Zncl}_{2}$ and $\mathrm{Pbcl}_{2}$ respectively per $1000 \mathrm{ml}$ and stored at refrigerator temperature (Seralathan et al., 2008; Shameer and Paramageetham, 2015).

Metal solution preparation: The metal solutions of three salts $\left(\mathrm{CuCl}_{2}, \mathrm{Zncl}_{2}\right.$ and $\left.\mathrm{Pbcl}_{2}\right)$ were prepared from stock solution in different concentrations $100 \mathrm{mg} / \mathrm{L}, 200 \mathrm{mg} / \mathrm{L}, 300 \mathrm{mg} / \mathrm{L}, 400 \mathrm{mg} / \mathrm{L}$, $500 \mathrm{mg} / \mathrm{L}$ and $600 \mathrm{mg} / \mathrm{L}$ (Seralathan et al., 2008; Shameer and Paramageetham, 2015).

Inoculation of culture into different metal concentration ( YIImaz IE., 2003):

The metal tolerance of each isolate was assayed by tube dilution method in sterile conical flasks of $250 \mathrm{ml}$ capacity. $100 \mathrm{ml}$ of metal solutions of each metal inoculated with $10 \mathrm{ml}$ overnight culture of isolates into properly labeled conical flasks. The $\mathrm{pH}$ of the metal microbe suspension was determined from the previously reported data ( Murthy et al., 2012; Areco et al., 2012; Chang et al., 1997; Govarthanan et al., 2016) and was adjusted to their respective $\mathrm{pH}$ to examine the metal tolerance capacity at their optimum $\mathrm{pH}$. The conical flasks were incubated at their optimum temperature $\left(37^{\circ} \mathrm{C}\right)$ for three days. A control without bacterial culture was also maintained. Each maintained in triplicates. The metal tolerance was analyzed calorimetrically by taking O.D values at $620 \mathrm{n}$.m after 72 hours (Figs. 3, 4 and 5).

Morphological characterization: A standard procedure namely Gram Staining technique was performed as described by (Reddy et al., 2007 and Bergey's et al., 1974). The slides are observed under $45 X$ objective lenses for examining Gram reaction and its morphological appearances such as color and the shape of bacterial colony are tabulated in Table 1.

Biochemical characterization: A few biochemical tests were performed for selected bacterial colonies, such as Indole, Methyl red-Voges proskauer, Citrate utilization, Catalase, Starch hydroly- 
sis, multiple sugar analysis as described by Reddy et al. (2007) and Bergey's et al. (1974) (Table 2).

\section{Molecular characterization}

DNA extraction: The Insta GeneTM Matrix Genomic DNA isolation kit was used to extract genomic DNA from bacteria. As per the instructions specified on the kit, genomic DNA was extracted from the individual isolates.

PCR protocol: Gene fragment was amplified in MJ Research Peltier Thermal Cycler by utilizing 16SrRNA universal primerswhich are mentioned below.

PCR amplification: The primers 27F 5' (AGA GTT TGA TCM TGG CTC AG) 3' and 1492R 5' (TAC GGY TAC CTT GTT ACG ACT T) 3' are used for the PCR of $16 S$ rRNA.

Purification of PCR products: Unincorporated PCR primers and dNTPs were removed from PCR products by using Montage PCR Clean up kit (Millipore).

The PCR product was sequenced using the 785F/907R primers.

Sequencing primers: The purified PCR were sequenced by using 2 primers those are:

785F 5' (GGA TTA GAT ACC CTG GTA) 3' and 907R 5' (CCG TCA ATT CMT TTR AGT TT) 3' are used for the Sequencing of 16S rRNA.

The sequences obtained were BLAST in NCBI to attain homologous sequences followed by phylogenetic analysis of the individual isolates using MEGA 7soft ware (Kumar et al., 2007) (fig: 4) by Neighbour Joining method (Saitou and Nei., 1987). The evolutionary distances were computed using the maximum composite likelihood joining method (Tamura et al., 2004).

\section{RESULTS AND DISCUSSION}

Metal analysis: The analysis of Heavy metals concentration present in the selected soil sample showed that heavy metals specifically $\mathrm{Cu}, \mathrm{Zn}$ and $\mathrm{Pb}$ are present in high concentration in compliance with WHO (2006) standards and these heavy metals have also been recognized as metals of immediate concern by WHO (2010) and (Hamid et al ., 2017).

Isolation and identification of metal tolerant bacterial strains: The range of metal tolerance in selected strains against $\mathrm{Cu}, \mathrm{Zn}$ and $\mathrm{Pb}$ was reported previously. The metal tolerance against three heavy metals ranging from $60 \mathrm{ppm}$ to $100 \mathrm{ppm}$ were selected for further analysis of metal concentration above $500 \mathrm{mg} / \mathrm{L}$ and identification studies (Sridevi et al., 2018). The strains were designated as VSR201, VSR202, VSR203 and VSR204. Four bacterial strains showed different cell shapes, colony characters and gram staining reactions (Table 1). The characterization of bacterial isolates (VSR201, VSR202, VSR203 and VSR204) based on their cultural, morphological and biochemical studies are specified in Table 1 and 2 respectively. The colony morphological characters were distinct among isolates. VSR201 was small circular off white, translucent, creamy and yellowish to creamy in color. VSR 202 was off white raised, rough colony with irregular margin, VSR203 was creamy opaque, and VSR204 was like white branched but with medium size.

The morphological characterization studies revealed that among four bacterial strains, two are gram positive rods and two are gram negative rods. Further identification was done by biochemical (Table 2) and molecular studies. Isolates

Table 1. Morphological characterization of the selected isolates.

\begin{tabular}{|c|c|c|c|c|c|}
\hline Strain & $\begin{array}{l}\text { Gram's } \\
\text { staining }\end{array}$ & Colony color & $\begin{array}{l}\text { Colony } \\
\text { elevation }\end{array}$ & Surface & Shape and size \\
\hline P. cookie & G've-rod & $\begin{array}{l}\text { Yellowish } \\
\text { creamy }\end{array}$ & Raised & Smooth & Circular-small \\
\hline B. cereus & $\mathrm{G}^{+} \mathrm{ve}-$ rod & Off white & Raised & Rough & Irregular edge- medium \\
\hline Aneurini bacillus sp. & $\mathrm{G}^{+}$ve -rod & Creamy & Opaque & Smooth & Slightly crenate edge-medium \\
\hline P. dentritiformis & G've-rod & White & Flat & Smooth & Branched-medium \\
\hline
\end{tabular}

Table 2. Biochemical characterizations of the selected isolates.

\begin{tabular}{lllll}
\hline Test & VSR & VSR & VSR & VSR \\
& $\mathbf{2 0 1}$ & $\mathbf{2 0 2}$ & $\mathbf{2 0 3}$ & $\mathbf{2 0 4}$ \\
\hline Indole & - & - & - & + \\
Methyl red & + & - & - & + \\
Voges proskauer & - & - & - & - \\
Citrate utilization & - & - & - & - \\
Catalase & - & + & + & + \\
Starch hydrolysis & - & - & - & + \\
Multiple sugar analysis: & & & - & - \\
Glucose & + & - & + & - \\
Sucrose & + & - & - & + \\
Mannitol & + & - & & \\
\hline
\end{tabular}

+ = Positive; - = Negative; +/- = Variable 
Sridevi, V. and Raghuram, M. / J. Appl. \& Nat. Sci. 11(2): 486- 491 (2019)

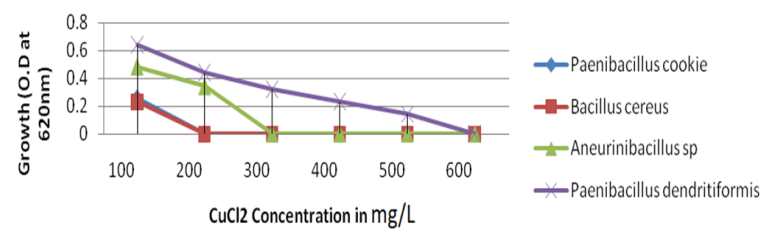

Fig.1. Growth of selected isolates (O.D at 620n.m) at different concentrations of $\mathrm{CuCl} 2$ after 72 hours of incubation.

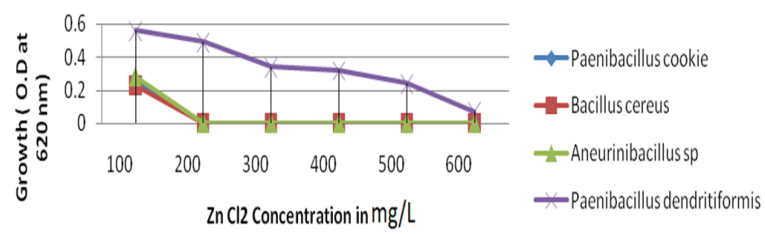

Fig. 2. Growth of selected isolates (O.D at 620n.m) at different concentrations of $\mathrm{ZnCl} 2$ after 72 hours of incubation.

VSR202 and VSR203 showed negative result for almost all biochemical tests except for catalase and sugar fermentation test. Only one isolate VSR201 ferment the mannitol.

The isolates finally identified up to species level were as Paenibacillus cookie (VSR201), Bacillus cereus (VSR202), Aneurini bacillus (VSR203), Paenibacillus dendritiformis (VSR204) by 16s rRNA characterization studies and based on partial sequence comparison by NCBI BLAST. 16S rRNA studies were performed for nine bacterial strains using universal primers with a length of 1492 bp. Amplified products were run in $1.0 \%$ agarose gel electrophoresis and observed' in UV light. The Amplified DNAs were sequenced and isolates were identified by Gene Bank database by comparing the sequences with those in NCBI and identified as strains which show more than 99\% similarity using BLAST search programme and sequences were submitted to NCBI. The assigned accession numbers for the submitted sequences are MK100333 (Paenibacillus cookie), MK100334 (Bacillus cereus), MK100335 (Aneurini bacillus $s p$ ) and MK100387 (Paenibacillus Sp.). The phylogenetic tree is shown as Fig. 4 based on 16S rRNA gene sequences. With the bootstrap value of $100 \%$, strain Paenibacillus Sp. VSR204 was grouped with $P$. dentritiformis strain CS2a4 (KU601317) and Paenibacillus sp.BAB-3430 (KF917150), and had a closer genetic relationship with $P$. dentritiformis. Thus, strains VSR204 belonged to $P$. dentritiformis. Though there was a much less generic diversity among bacteria, strains showed biochemical diversity within them.

Determination of metal tolerance: Four bacterial isolates exhibited metal tolerance against selected metals up to $100 \mathrm{ppm}$. Hence further study was carried out by subjecting bacterial isolates to high metal concentration $(100 \mathrm{mg} / \mathrm{L}, 200 \mathrm{mg} / \mathrm{L}, 300 \mathrm{mg} /$ $\mathrm{L}, 400 \mathrm{mg} / \mathrm{L}, 500 \mathrm{mg} / \mathrm{L}$, and $600 \mathrm{mg} / \mathrm{L})$ at their optimum $\mathrm{pH}$ and temperature.

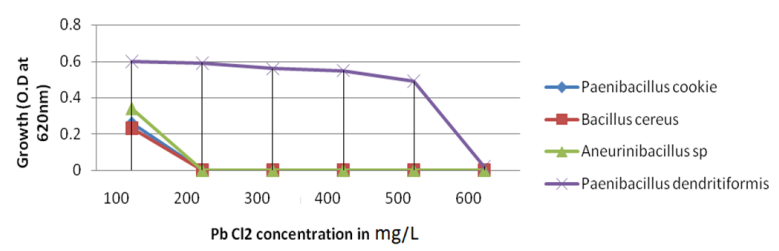

Fig. 3. Growth of selected isolates (O.D at 620n.m) at different concentrations of $\mathrm{PbCl} 2$ after 72 hours of incubation.

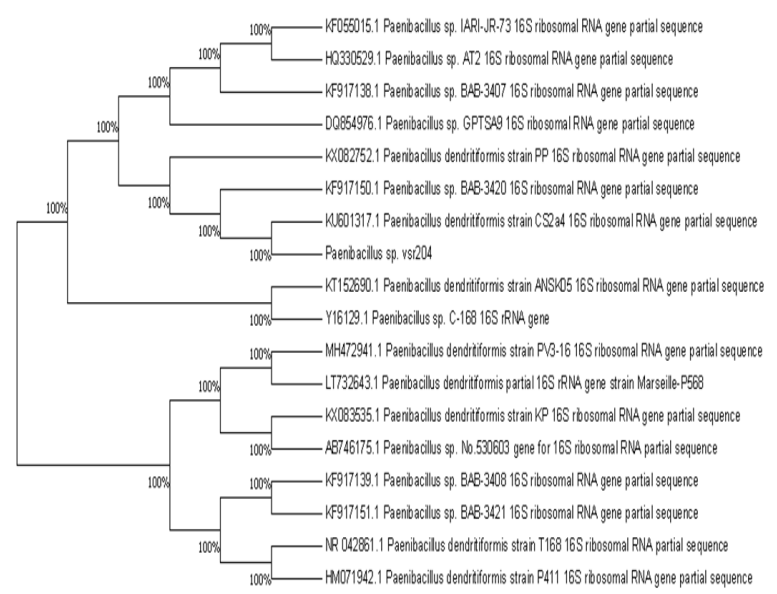

Fig. 4. Phylogenetic Analysis of 16s rRNA gene sequence of $P$. dentritiformis by Neighbour Joiing Method.

Out of four strains particularly one strain that is $P$. dentritiformis exhibited high metal tolerance against all three metals $(\mathrm{Pb}>\mathrm{Zn}>\mathrm{Cu})$ at its optimum $\mathrm{pH}$, this is a unique feature of $P$. dentritiformis to survive in different environmental metal pollutants. Rest of three strains Paenibacillus cookie, Bacillus cereus and Aneurini bacillus species showed their maximum growth at 100ppm. The growth was effected totally from $200 \mathrm{mg} / \mathrm{L}$ and completely absent after $300 \mathrm{mg} / \mathrm{L}$ against lead and zinc even at their optimum $\mathrm{pH}$ after 72 hours of incubation (Figs. 1, 2 and 3).

Unlike that of Paenibacillus cookie and Bacillus cereus, $A$. bacillus species showed its growth at least up to $200 \mathrm{mg} / \mathrm{L}$ concentration of copper (Fig.1) but after that the growth was affected by increasing metal concentration. $P$. dentritiformis is the only strain among all strains tested exhibited highest lead tolerance up to $500 \mathrm{mg} / \mathrm{L}$ at acidic $\mathrm{pH}$ after 72 hours. There was a steady growth rate observed until $400 \mathrm{mg} / \mathrm{L}$ concentration of lead and then the growth was reduced suddenly by increasing lead concentration from $500 \mathrm{mg} / \mathrm{L}$ even at its optimum pH (Fig. 3). Against to copper and zinc the growth was reduced gradually by increasing metal concentration (Figs. 2 and 3 ) and it was observed to absent after $500 \mathrm{mg} / \mathrm{L}$. The results of $P$. dentritiformis to zinc and copper tolerance was similar with the earlier studies reported by Shruti Murthy et al. (2013). In accordance with those studies it was clearly evident that the growth rate 
was reduced gradually by increasing metal concentration.

However, there are some studies reported that the microorganisms have the ability to grow even at high concentration of metals without affecting their growth this is due to the results of intrinsic factors or due to induced mechanisms as well as other environmental factors (Xiao et al., 2010; Zouboulis et al., 2004; Leedjarv et al ., 2008). The similar scenario was observed in case of $P$. dentritiformis which showed unique pattern of growth rate in lead solution. Surprisingly the growth rate was constant until $400 \mathrm{mg} / \mathrm{L}$ and latter it became slower at $500 \mathrm{mg} / \mathrm{L}$ concentration followed by absences of growth after 72 hours at $600 \mathrm{mg} / \mathrm{L}$ concentration of lead, this is may be due to the presence of its favorable temperature and $\mathrm{pH}$.

From the literature, it is evident that $\mathrm{Zn}$ will get precipitate at $\mathrm{pH}$ 6-7 (Areco et al., 2012) and $\mathrm{pH}$ beyond 5 will decreases the lead solubility (Chang et al 1997) may be this is the reason why $P$. dentritiformis showed zinc and lead tolerance up to $500 \mathrm{mg} / \mathrm{L}$ at $\mathrm{pH} 5$. The lead tolerance of $P$. dendritiformis reported in this study similar to Bacillus cereus showed lead tolerance up to $500 \mathrm{mg} / \mathrm{L}$ at temperature $30^{\circ} \mathrm{C}$ and $\mathrm{pH} 5$ reported by Shruti Murthy et al., (2012). And it is relatively high than the recently reported Paenibacillus $s p$. RM showed lead resistant up to $450 \mathrm{mg} / \mathrm{L}$ after 48 hours (Govarthanan et al., 2016).

Hao et al. (1994) reported that zinc concentration ranging from 25 to $40 \mathrm{ppm}$ can cause death of microorganisms. In contrast to this Govarthanan et al., (2016) reported that the Paenibacilius sp.RM exhibited highest metal resistant to zinc up to $500 \mathrm{mg} / \mathrm{L}$ and similarly in this study the ability of strain $P$. dendritiformis to grow at their optimum $\mathrm{pH}$ and temperature in presence of a wide range of $100 \mathrm{mg} / \mathrm{L}, 200 \mathrm{mg} / \mathrm{L}, 300 \mathrm{mg} / \mathrm{L}, 400 \mathrm{mg} / \mathrm{L}, 500$ $\mathrm{mg} / \mathrm{L}$ and $600 \mathrm{mg} / \mathrm{L}) \mathrm{Zncl}_{2}$ have suggested that they have the zinc tolerance up to $500 \mathrm{mg} / \mathrm{L}$. Mohammed Umar and Normala (2015) reported that bacterial isolate (MH4) showed high degree of resistance to copper up to $200 \mathrm{mg} / \mathrm{l}$. However, the previous study done by Govarthanan et al., (2016) stated that Paenibacilius sp.RM exhibited copper resistant up to $750 \mathrm{mg} / \mathrm{L}$. In this study $P$. dendritiformis showed copper tolerance up to $500 \mathrm{mg} / \mathrm{L}$ at temperature $37^{\circ} \mathrm{C}, \mathrm{pH} 7.2$ for 72 hours and taking the result of this study in to consideration we can assume that the strains at their optimum $\mathrm{pH}$ and temperature can able to exhibit a high metal tolerance.

\section{Conclusion}

In this study, $P$. dentritiformis MK100387 showed tolerance against three selected metals. The metal presence not effected much the growth of selected isolate during analysis. The results presented in this study proved that the isolated strain i.e
$P$. dentritiformis is best suitable for the treatment of metal contaminated soils, industrial effluents that contains copper, zinc and lead as metal contaminants. And further genomic studies are required for the isolation and characterization of metal tolerant genes.

\section{ACKNOWLEDGEMENTS}

The authors thank the Department of Microbiology Acharya Nagarjuna University Nagarjuna Nagar, ASN aqua labs Bhimavaram and B.V.Raju College Vishnupur Bhimavaram who provided insight and expertise that greatly assisted the research and for their continuous encouragement in the successful completion of this project work.

\section{REFERENCES}

1. Hookoom M, Puchooa D (2013) Isolation and identification of heavy metals tolerant bacteria from industrial and agricultural areas in Mauritius. Curr Res Microbiol Biotechnol., 1:119-123

2. Smrithi A, Usha K (2012) Isolation and characterization of chromium removing bacteria from tannery effluent disposal site. Int. J. Adv. Biotechnol. Res., 3:644-652.Open Access.

3. Shuttleworth KL, Unz RF (1993) Sorption of heavy metals to the filamentous bacterium Thiothrix strain A1. Appl. Environ. Microbiol., 59:1274-1282.

4. Salinas E, Melorza DO (2000) Removal of cadmium and lead from dilute aqueous solution by Rhodotorularuba. Bioresour Technol., 72:107112.

5. Anoop K, Viraraghvan T (1999) Removal of heavy metals using the fungus Aspergillus niger. Bioresour Technol., 70:95-104. https://doi.org/10.1016/s09608524(98)00192-8.

6. Ahuja P, Gupta R (1999) $\mathrm{Zn+2}$ biosorption by Oscillatoria angustissima. Process Biochem., 34:77-85.

7. Yasar A, Khan M, Tabinda AB, Hayyat MU, Zaheer A (2013) Percentage uptake of heavy metals of different macrophytes in stagnant and flowing textile effluent. J Anim Plant Sci.,23:1709-1713.

8. V. Sridevi, M.Raghuram and D. Ravisankar (2018) Isolation and Screening of Heavy Metal Resistant Microorganisms from Industrial Soil. Journal of Pure and Applied Microbiology, Sept. 2018. Vol. 12(3): 1667-1674. http://dx.doi.org/10.22207/JPAM.12.3.75.

9. F. Abraham Samuel, V. Mohan and L. Jeyanthi Rebecca (2014) Physicochemical and heavy metal analysis of sugar mill effluent. J. Chem. Pharm. Res., 2014, 6(4):585-58. Open Access.

10.Suresh B, Sudhakar. G, Damodharam T.(2015). Determination of Heavy Metals in Sugar Industry Effluent, International Journal of Modern Engineering Research (IJMER), Vol. 5, Iss.4. Open Access.

11.Usha Damodhar and M. Vikram Reddy (2012). Assessment of trace metal pollution of water and sediment of river Gadilam (Cuddalore, South east coast of India) receiving sugar industry effluents. Continental J. Environmental Sciences, 6 (3): $8-24$

12.R. A. Ansari, A. A. Qureshi \& D. S. Ramteke (2016). Isolation and characterization of heavy-metal resistant microbes from Industrial soil. International Journal Of Environmental Sciences, Volume 6, No5, 2016. doi: 10.6088/ijes.6063. 
13.Seralathan Kamala-Kannan and Kui Jae Lee (2008). Metal Tolerance and Antibiotic Resistance of Bacillus species Isolated from Sunchon Bay Sediments, South Korea, 7 (1): 149152. DOI: 10.3923/biotech.2008.149.152.

14. Shameer Syed and Paramageetham Chinthala (2015). Heavy Metal Detoxification by Different Bacillus Species Isolated from Solar Salterns. http://dx.doi.org/10.1155/2015/319760

15.Shruti Murthy, Geetha balli and S.K. Sarangi (2013). Effect of lead on growth, protein and biosorption capacity of Bacillus cereus isolated from industrial effluents. A Journal of Environmental Biology.

16.YIImaz IE (2003) Metal tolerance and biosorption capacity of Bacillus circulans strain EB1. Res Microbiol.,154:409-415. https://doi.org/10.1016/S09232508(03)00116-5.

17.Reddy CA, Beveridge TJ, Breznak JA, Marzluf G (2007). Methods for general and molecular microbiology. (3rdedn), ASM Press, ASM, Washington DC.

18.Shruti Murthy, Geetha Bali and S. K. Sarangi (2012). Biosorption of Lead by Bacillus cereus Isolated from Industrial Effluents. British Biotechnology Journal, 2 (2): 73-84, 2012.

19.M.M. Areco, S. Hanela, J. Duran, M.D.S. (2012). Afonso Biosorption of $\mathrm{Cu}(\mathrm{II}), \mathrm{Zn}(\mathrm{II}), \mathrm{Cd}(\mathrm{II})$ and $\mathrm{Pb}(\mathrm{II})$ by dead biomasses of green alga Ulva lactuca and the development of a sustainable matrix for adsorption implementation. J Hazard Mater, 2134 , 123-132. https://doi.org/10.1016/ j.jhazmat.2012.01.073.

20.Chang, J.S., Law, R., Chang, C. (1997). Biosorption of lead, copper and cadmium by biomass of Pseudomonas aeruginosa PU 21. Water Research, 31: 1651 -1658. http://dx.doi.org/10.1016/S0043-1354(97) 00008-0.

21.M. Govarthanan, R. Mythili, T. Selvankumar, S. Kamala-Kannan, A. Rajasekar and Young-Cheol Chang (2016). Bioremediation of heavy metals using an endophytic bacterium Paenibacillus $s p$. RM isolated from the roots of Tridaxprocumbens. Biotech. 6:242. doi: $10.1007 / \mathrm{s} 13205-016-0560-1$.

22.D.H. Bergey, R.E. Buchanan, N.E. Gibbons (1974). Bergey's Manual of Determinative Bacteriology (eighth ed.), Williams and Wilkins Co., Baltimore,pp 1246

23.A. Hamid, A. Mushtaq, R. Nazir and S. Asghar (2017). Heavy metals in soil and vegetables grown with municipal wastewater in Lahore. Bangladesh. $J$.
Sci. Ind. Res., 52(4), 331-336. DOI: https:// doi.org/10.3329/bjsir.v52i4.34821.

24.XiaoX., Luo S.L., Zeng G.M, Wei W.Z., Wan Y., Chen L., Guo H.J., Cao Z., Yang L.X., Chen J.L., Xi Q., 2010. Bioabsorption of cadmium by endophyticus fungus (EF) Microsphaeropsis $s p$. LSE10 isolated from cadmium hyperaccumulator Solanum nigrum $\mathrm{L}$. Bioresour. Technol., 101, 1668-1674 doi: 10.1016/ j.biortech.2009.09.083.

25.Zouboulis, A.I., Loukidou, M.X., Martis, K.A., 2004. Biosorption of toxic metals from aqueous solutions by bacteria strains isolated from metal polluted soils. Process Biochem., 39 909-916. DOI: 10.1016/s00329592(03)00200-0

26.Leedjarv, A., Ivask, A., Virta, M., 2008. The interplay of different transporters in the mediation of divalent heavy metal resistance in Pseudomonas putida KT2440. J.Bacteriol., 190 2680-2689. doi: 10.1128/ JB.01494-07

27.M. Govarthanan, R. Mythili, T. Selvankumar, S. Kamala-Kannan, A. Rajasekar and Young-Cheol Chang (2016). Bioremediation of heavy metals using an endophytic bacterium Paenibacillus sp. RM isolated from the roots of Tridaxprocumbens. Biotech., 6:242. DOI 10.1007/s13205-016-0560-1.

28.Hao, O.J., Huang, L., Chen, J.M., Buglass, R.L. (1994). Effects of metal additions on sulfate reduction activity in wastewaters. Toxicological and Environmental Chemistry, 46, 197-212. https:/l doi.org/10.1080/02772249409358113.

29.Mohammed Umar Mustapha and NormalaHalimoon. (2015). Screening and isolation of heavy metal tolerant bacteria in industrial effluent. Procedia Environmental Sciences, 30: 33 - 37. https://doi.org/10.1016/ j.proenv.2015.10.006.

30.Saitou N. and Nei M. (1987). The neighbor-joining method: A new method for reconstructing phylogenetic trees. Molecular Biology and Evolution, 4:406425. DOI: 10.1093/oxfordjournals.molbev.a040454.

31.Tamura K., Nei M., and Kumar S. (2004). Prospects for inferring very large phylogenies by using the neighbor-joining method. Proceedings of the National Academy of Sciences (USA), 101:11030-11035. DOI: 10.1073/pnas.0404206101.

32.Kumar S., Stecher G., and Tamura K. (2016). MEGA7: Molecular Evolutionary Genetics Analysis version 7.0 for bigger datasets. Molecular Biology and Evolution, 33:1870-1874. doi: 10.1093/molbev/ msw054. 